\title{
LOSY POLSKICH ŻOLNIERZY ERY NAPOLEOŃSKIEJ W ŚWIETLE KAZAŃ I MÓW OKOLICZNOŚCIOWYCH Z OKRESU KSIĘSTWA WARSZAWSKIEGO I KRÓLESTWA POLSKIEGO
}

W drugiej połowie XVIII w. agresywnie nastawieni sąsiedzi Rzeczpospolitej (Rosja, Prusy i Austria) zdecydowali o jej losie. Zgodnie z ówczesną polityczną praktyką, podzielili się ziemiami i mieszkańcami ogarniętego kryzysem państwa, wymazując go z mapy Europy. Aby je odzyskać, Polacy musieli więc chwycić za broń i walczyć o niezależność. Im dłużej to czynili, walka ta w znacznej mierze determinowała ich losy.

Temu determinizmowi sprzyjał nowoczesny świat, tworzący się w rewolucyjnych i insurekcyjnych wstrząsach końca XVIII w. i pierwszej połowy XIX stulecia, przyciągający wiele osób gotowych poświęcić samych siebie. Wtedy to, jak pisał w Świętym Szaleństwie Adam Zamoyski: „Liczni młodzi ludzie, napędzani przemożną chęcią zbawienia ludzkości i siebie samych, walczyli i ginęli jako uczestnicy niby-krucjaty, w której miejsce Jerozolimy zajmował wyidealizowany obraz Naszego Pana Ludzkości, czyli narodu - wierzyli przy tym, że śmierć w służbie owego ideału zapewni im status męczenników i życie wieczne"1. Wśród nich nie zabrakło Polaków, m.in. toczących boje w wojnach epoki napoleońskiej, których ,święte szaleństwo", zbiegające się z katastrofą utraty państwa, miało nieść wolność innym narodom, a zarazem służyć odzyskaniu własnej.

O tym „szaleństwie” dowiedzieć się można było z kazań i mów okolicznościowych czasów Księstwa Warszawskiego i Królestwa Polskiego. Te bowiem wygłaszane przez duchownych na pogrzebach, przed rozpoczęciem obrad sejmu, na nabożeństwach z udziałem wojska oraz uroczystościach organizowanych ku czci panujących, obok treści stricte religijnej zawierały aktualną problematykę społeczno-polityczną, w tym informacje na temat walczących o odzyskanie kraju Polaków². Informacje, dzięki którym można podjąć próbę odtworzenie ich losów.

\footnotetext{
A. Zamoyski, Święte szaleństwo. Romantycy, patrioci, rewolucjoniści 1776-1871, tłum. M. Ronikier, Kraków 2015, s. 11.

2 Por. J. Związek, Rzeczywistość historyczna w kazaniach, Częstochowa 2009, s. 23-34; J. S. Pasierb, Kaznodziejstwo $w$ religijnej $i$ narodowej strukturze polskiego tysiaclecia, „Collectanea Theologica” 38 (1968), f. 2, s. 105.
} 
Sama próba nie jest niczym nowym, bo kazania pochodzące z podanych w temacie periodów rodzimych dziejów w swoich pracach wykorzystywali, traktując jako źródła historyczne, Monika Hamanowa ${ }^{3}$, Ewa Ziółek ${ }^{4}$ czy Kazimierz Panuśs. Nowością jednak jest skupienie się w niniejszym artykule na wiadomościach zawartych w kaznodziejskich wystąpieniach, o wojennych doświadczeniach pozbawionych w wyniku rozbiorów państwa Polaków. Przy czym, aby te wiadomości mogły być właściwie zinterpretowane, gdyż kazania nie stanowią zapisu kronikarskiego, ale zalicza się je do dzieł literackich, niezbędne stało się sięgnięcie po dotyczące tematu opracowania, m.in. Jana Pachońskiego, Jerzego Skowronka, Ryszarda Przybylskiego.

Co do analizowanych kazań i mów, to wykorzystane zostały m.in. autorstwa wybitnego kościelnego mówcy, biskupa-poety Jana Pawła Woronicza ${ }^{6}$, biskupa płockiego Adama Michała Prażmowskiego ${ }^{7}$, prałata kapituły krakowskiej i archiprezbitera kościoła mariackiego Józefa Wincentego Łańcuckiego ${ }^{8}$, archidiakona wileńskiego Michała Dłuskiego ${ }^{9}$, nauczyciela i pioniera kształcenia dzieci głuchych ks. Jakuba Falkowskiego ${ }^{10}$, profesora Uniwersytetu Warszawskiego ks. Wojciecha Anzelma Szweykowskiego ${ }^{11}$, jak również akademika warszawskiego ks. Franciszka Ksawerego Szaniawskiego ${ }^{12}$.

$\mathrm{Z}$ nich to Szaniawski właśnie przypisywał stanowi żołnierskiemu najwyższe poświęcenie i szczególne umiejętności oraz predyspozycje duchowe. „Niezliczone są sposoby, przez które pomagamy ojczyźnie - wyjaśniał warszawski profesor wszystkie stany w towarzystwie ludzkim przyczyniają się do jej dobra, lecz obrońcy kraju, wojskowe osoby, widoczniejsze i bezpośrednie ofiary, bo całych siebie,

3 Zob. M. Hamanowa, Treści społeczne w kazaniach z okresu Księstwa Warszawskiego, w: Historia, idee, polityka. Księga dedykowana Profesorowi Janowi Baszkiewiczowi, red. F. Ryszka, Warszawa 1995, s. 201-209; M. Hamanowa, Obraz śmierci w kazaniach z czasów Księstwa Warszawskiego, „Napis” 5 (1999), s. 169-175.

4 Zob. E. M. Ziółek, O cnotliwym urzędniku i dobrym obywatelu. Kanonika Augustyna Lipińskiego filozofia sprawowania władzy (na kanwie kazania wygłoszonego 8 maja 1810 roku w Krakowie), „Roczniki Humanistyczne” 61 (2013), z. 2, s. 283-293.

5 Zob. K. Panuś, Uratować naród! Głos z ambony katedry wawelskiej okresu niewoli narodowej 1795-1918, Kraków 1996, s. 159-220.

6 Zob. Z. Rejman, Jan Paweł Woronicz. Poeta i kapłan, Chotomów 1992.

7 Zob. B. Kumor, Prażmowski Adam Michat, w: Stownik polskich teologów katolickich [dalej: SPTK], t. 3, Warszawa 1982, s. 438-440.

8 Zob. tenże, Łańcucki Józef Wincenty, w: SPTK, t. 2, Warszawa 1982, s. 549-550.

9 Zob. M. Banaszak, Michat Dluski, w: SPTK, t. 1, Warszawa 1981, s. 399-400.

10 Zob. L. Grochowski, Ksiądz Jakub Falkowski (1775-1848) - pionier nauczania dzieci głuchych na ziemiach polskich. Z dziejów dziedzictwa edukacyjnego ojców pijarów, w: Wkład pijarów do nauki i kultury w Polsce XVII-XIX wieku, red. I. Stasiewicz-Jasiukowa, Warszawa-Kraków 1993, s. 501-527.

11 Zob. H. E. Wyczawski, Szweykowski Wojciech Anzelm, w: SPTK, t. 4, Warszawa 1983, s. 287-289.

12 Zob. H. E. Wyczawski, Szaniawski Franciszek Ksawery, w: SPTK, t. 4, s. 248-250. 
wszystkie swe siły życiowe nawet dla dobra kraju łożą. Szacowny stan wojskowy; trudne są jego obowiązki; wiele zdatności, nauki, doświadczenia, zwłaszcza w stopniach wyższych, a nade wszystko niewzruszonej stałości duszy wymaga, aby obfite pożytki ojczyźnie przynosił"'3. Podkreślić jednak należy, że ta apoteoza wojskowego fachu, dokonana na nabożeństwie żałobnym za generała Jana Henryka Dąbrowskiego, korespondowała ściśle z tym, co z ambon konfratrzy ks. Szaniawskiego opowiadali o zbrojnym wysiłku polskich żołnierzy - o pokoleniowym doświadczeniu poniewierki i walki na obczyźnie, której przeznaczeniem finalnym miało być dobro ojczyzny. Bo, jak głosił o. Paweł Szulczewski, chociaż ,zdrada potrafiła z rąk wojowników naszych oręż wytrącić, ale nie zdołała sercom odjąć męstwa" ${ }^{14}$.

Nim wykazali się ci, którzy według ks. Szweykowskiego, postanowili szukać ojczyzny tam, gdzie trwały zmagania o wolność: „Gdzie jest walka, mówią, za wolność, tam szukać będziem ojczyzny! Tam blizny odniesione, będą jeszcze dla niej ofiarą"15. W konsekwencji bojownikom tym przyszło zaznać tułaczego losu, o którym Szweykowski mówił w ten sposób: „Doświadczone męstwo Polaków zapędziło ich w różne części świata, zebrani daleko, jeszcze się dalej po lądzie i morzu rozproszyli" ${ }^{\prime \prime}$. A uczynili to z pomocą zrewoltowanej Francji, a następnie cesarza Napoleona Bonapartego.

Przypominał o tym w trakcie warszawskiego pogrzebu księcia Józefa Poniatowskiego w 1814 r. ks. Woronicz. Wołał on wówczas: „Wzywam was tu z czterech końców szerokiego świata. I was, którzyście ziemię rodzinną Pompejuszów szukaniem zbrojnym wolności i niepodległości waszej lat tyle pocieszali. I was, którzyście po skalistych urwiskach Pirenejów zardzewioną sławę pobratnich naszych Wandalitów

${ }_{13}$ F. K. Szaniawski, Mowa na nabożeństwie żałobnym za duszę śp. Jana Henryka Dąbrowskiego 17. czerwca roku 1818 w kościele Sgo Krzyża w Warszawie, w: Kazania, t. 3, Warszawa 1820, s. 332-333.

14 P. Szulczewski, Kazanie pierwsze miane $w$ czasie żałobnego nabożeństwa za poległych w sprawie ojczyzny braci naszych Polaków w kościele WW. OO. Bernardynów dnia 6 października roku 1808, w: Dwa kazania żałobne, Rawicz 1809, s. 5.

15 W. Szweykowski, Kazanie do nowo zaciężnych obrońców ojczyzny, miane wśród uroczystości poprzedzającej przysięge wojskowa korpusu JW. Generała Woyczyńskiego, w kościele katedralnym płockim, dnia 8 marca roku 1807, [b.m.r.], knlb. 6v.

16 Tamże, knlb. 6v. W podobnym tonie przemawiał do posłów zgromadzonych na sejmie Księstwa Warszawskiego w 1809 r. ks. Jan Paweł Woronicz: „I czegóż przecie te niezagubne plemienniki wasze po lądach i morzach szukają? Ojczyzny!” (J. P. Woronicz, Kazanie przy pierwszym otwarciu Sejmu Głównego Księstwa Warszawskiego miane w kościele katedralnym warszawskim, dnia 10. miesiaca marca roku 1809, Warszawa 1809, s. 10). Także ks. Józef Wincenty Łańcucki w 1818 r. zgromadzonym na pogrzebie Tadeusza Kościuszki przypominał, że choć wymazano Polskę z mapy Europy, to przetrwał duch prawych Polaków, który „po całym świecie rozlany, wszędzie za świętym ojczyzny uganiał się cieniem" (J. W. Łańcucki, Kazanie w czasie uroczystych obrzędów pogrzebu ciała śp. Tadeusza Kościuszki w kościele katedralnym krakowskim dnia 23 czerwca 1818, Kraków [b.r.], s. 37). 
świetnym orężem odkopywali. I was, krain Sezostrysa orężni wędrowcy. I was na koniec, zabójczego wyspu Domingi smutne ofiary. Wzywam was tu - stańcie, otoczcie ten śmiertelnością tlejący majestat wodza waszego!" ${ }^{17}$. Woronicz w tym kazaniu, skrótowo lecz w pełnych wzniosłej poetyki określeniach, zaprezentował miejsca, gdzie bili się nieposiadający ojczyzny Polacy - we Włoszech, Hiszpanii, Egipcie, na San Domingo. Wspominał także wyprawę moskiewską oraz odwrót po przegranej, w czasie którego książę Poniatowski przez „miasta i gościńce krain germańskich [...] w karnym i porządnym szyku nie skalane niczym roty swoje przewodził”"18. Tym samym kościelny mówca przypominał swoim słuchaczom, iż Polacy po zdławieniu insurekcji kościuszkowskiej w 1794 r., nie zaprzestali walki.

Najistotniejszą z prób jej kontynuowania były Legiony Polskie sformowane we Włoszech w 1797 r. pod egidą Francji i walczące wraz z wojskiem francuskim i włoskim. Tak o tym braterstwie broni, o rodakach, którzy szli pod zwycięskie francuskie sztandary mówił o. Szulczewski: „Naród wolny, Naród waleczny, potrafił tę ich miłość swobód ojczystych, to ich męstwo docenić; podał im przyjacielską rękę, a w zapowiedniej nie jako dla ciemiężców zemście, osobne im pułki pod imieniem Legionów Polskich składać pozwoliwszy, imię Polaka zachował"19. W tórował mu ks. Szaniawski: „Nagłe zmiany w innych Europy częściach błysnęły nadzieją Polakom, że mogą bydź jeszcze narodem udzielnym; chwytają się gorliwie, choć słabych i niepewnych środków; idą w dalekie kraje, niezłomne przebywają zapory, pełnią najwierniej ważne usługi dla narodu, który im zaręcza, że z wzajemnym od niego wsparciem odzyskają własną ojczyznę"20. Podobnie alians z Francuzami thumaczył ks. Dłuski. W jego ocenie Polacy szli pod rozkazy Bonapartego, ,ażeby męstwem i ofiarą krwi swojej zjednali pomoc i wielowładną opiekę uciśnionym swym ziomkom”21.

17 J. P. Woronicz, Kazanie na pogrzebie sprowadzonych do Warszawy zwłoków śp. J[aśnie] O[świeconego] książęcia Józefa Poniatowskiego [1814], w: Jan Paweł Woronicz. Pisma wybrane, oprac. M. Nesteruk, Z. Rejman, Wrocław-Warszawa-Kraków 2002, s. 229. Siedem lat wcześniej, w 1807 r., przy uroczystym poświęceniu emblematów wojska Księstwa Warszawskiego, Woronicz odtwarzał szlak bojowy polskiego wojska walczącego w cudzoziemskich stronach pod przewodem Napoleona. „Któreż was lądy i morza nie znają? - pytał kaznodzieja - Które narody i języki imion waszych ze czcią i politowaniem nie wymawiają? Nadbrzeża Tybru, Padu, Rodanu, Sekwany, Renu, Dunaju i owe rówiennice świata, żyznego Nilu piramidy, i owe ogorzałe skwarem arabskie Izmaela pustynie! Zgoła, gdzie tylko dosięgnął oręż i sława Napoleona, tam i was niezbędna miłość ojczyzny za nim wlokła i potyrała”. J. P. Woronicz, Kazanie przy uroczystym poświęceniu orłów i choragwi polskich wojsku narodowemu nadanych [1807], w: Jan Pawet Woronicz. Pisma wybrane, oprac. M. Nesteruk, Z. Rejman, Wrocław-Warszawa-Kraków 2002, s. 194-195.

18 Tenże, Kazanie na pogrzebie... Józefa Poniatowskiego..., dz. cyt., s. 227.

19 P. Szulczewski, Kazanie pierwsze..., dz. cyt., s. 5.

${ }^{20}$ F. K. Szaniawski, Mowa na nabożeństwie żałobnym za duszę śp. Jana Henryka Dąbrowskiego..., dz. cyt., s. 328.

${ }^{21}$ M. Dłuski, Kazanie w dzień uroczystego obchodu imienin Najjaśniejszego i Najpotężniej- 
Rzeczywiście, poprzez czyn zbrojny, Legiony przypominały o dążnościach Polaków, o nieakceptowaniu przez nich rozbiorów. Uczyły ich demokracji, republikanizmu, współodpowiedzialności za rozwój Polski, umożliwiły nawiązanie kontaktów międzynarodowych - dyplomatycznych, wojskowych, ideowych i kulturalnych ${ }^{22}$. Dlatego zaciągający się w szeregi Legionów - emigranci, dezerterzy z armii zaborczych (Polacy przymusowo do nich wcieleni ${ }^{23}$ ), ochotnicy z francuskich obozów jenieckich ${ }^{24}$ - przelewali krew we wszystkich tych obcych miejscach, o których mówił Woronicz. Tęsknili jednak za ojczyzną i domem rodzinnym. Wierzyli, że niebawem wrócą w rodzinne strony ${ }^{25}$.

A przewodził im, co podkreślał ks. Szaniawski, generał Dąbrowski, biorąc udział w licznych bojach na obczyźnie ${ }^{26}$. On i jego żołnierze w zmaganiach tych wykazali się niebywałą walecznością, stając się wzorem dla najdalszych pokoleńn ${ }^{27}$. Tak

szego Napoleona Wielkiego Cesarza Francuzów, króla włoskiego, protektora Ligi Reńskiej, oswobodziciela Polski miane w kościele katedralnym wileńskim dnia 15 augusta 1812 roku, Wilno [b.r.], s. 12.

22 Zob. J. Pachoński, Legiony polskie. Prawda i legenda 1794-1807, t. 1, Działalność niepodległościowa i zaczatki legionów 1794-1797, Warszawa 1969, s. 6-7; S. Herbert, Żotnierze niepodległości, w: Polska w epoce oświecenia. Państwo-społeczeństwo-kultura, red. B. Leśnodorski, Warszawa 1971, s. 407-409; T. Łepkowski, Polska-narodziny nowoczesnego narodu 1764-1870, Warszawa 1967, s. 253-254.

23 Jeszcze za czasów Księstwa Warszawskiego ks. Jakub Falkowski wspominał o rodakach przymusowo wcielanych do zaborczych wojsk, którzy w zaistniałej sytuacji zamierzali złączyć się z obywatelami Księstwa, a daną im do zabijania współziomków broń skierować, „na odparcie przemocy najeźdźców naszych”. J. Falkowski, Mowa do ludu w czasie obchodu uroczystości dziękczynienia Bogu za zwycięstwo W. Napoleona otrzymane pod Rohr, miane dnia 8 maja 1809 w Szczucinie, [b.m.r.], s. 10.

24 Zob. J. Pachoński, Legiony polskie. Prawda i legenda 1794-1807, t. 4, „Z ziemi włoskiej do Polski” 1800-1807, Warszawa 1979, s. 618-621.

25 Na dowód tego badacz historii Legionów Polskich, Jan Pachoński, powoływał się na końcowy okres ich istnienia. Pomimo obietnic awansów i nagród w razie pozostania w Królestwie Neapolu, oficerowie polscy w zdecydowanej większości żądali powrotu do ojczyzny (zob. J. Pachoński, Oficerowie Legionów Polskich 1796-1807, t. 1, Korpus oficerski Legionów Polskich 1796-1807, Kraków 1999, s. 191-193). Odmienne przekonanie miało panować w kraju. Z kazania ks. Szweykowskiego wynikało, że wśród Polaków nie było nadziei na powrót legionistów (zob. W. Szweykowski, Kazanie do nowo zaciężnych..., dz. cyt., knlb. 6v).

${ }^{26}$ Zob. F. K. Szaniawski, Mowa na nabożeństwie żałobnym za duszę śp. Jana Henryka Dąbrowskiego..., dz. cyt., s. 329.

${ }^{27}$ Ks. Feliks Jaroński waleczność przypisywał w ogóle wszystkim polskim żołnierzom doby napoleońskiej: „Cudami waleczności ciągle i w różnych świata częściach świeżo okazywanemi zadziwili świat cały w zdumienie nieprzyjaciół wprowadzili i zasłużyli bydź wzorem dla najodleglejszych następców". F. Jaroński, Mowa na dzień obchodu imienin Najjaśniejszego Fryderyka Augusta króla saskiego, książęcia warszawskiego, dnia $3 g o$ sierpnia 1810 roku w kościele katedralnym krakowskim miana, Kraków [b.r.], knlb. 5v. 
też o tym mówił, wyliczając szczegółowiej zasługi militarne Polaków będących pod dowództwem Dąbrowskiego, Hiacynt Zakrzewski: „Mężnych Polaków hufce pod walecznym Twem zawiązane dowództwem, od Dunaju do Tybru, od Sekwany do Dniepru upadłego narodu odświeżyły sławę. Wtenczas Polak w jednej części południa, trudne do przebycia wojsku obcemu pod Somna-Siera otwiera wąwozy, i przy nurtach Tagu wsławiony opiera oręż, w drugiej stronie z licznych wojsk pierwszy, objąwszy posadę stolicy niegdy całego świata, wstępuje z uszanowaniem na Kamillów, Katonów, Scypionów, Pompejów groby, wspomnieniem ich wielkich dzieł rozżarzał w swem sercu, wrodzonej miłości do własnej ojczyzny zapał”28.

Ale pokój z Lunéville (1801 r.) między Republiką Francuską a Austrią, oznaczający rozpad II koalicji antyfrancuskiej, niweczył wiarę legionistów w rychły powrót do kraju. Francuzi bowiem postanowili rozwiązać Legiony, a ich żołnierzy wcielić do swojej armii, tworząc z nich półbrygady cudzoziemskie. Ostateczny kres Legionom przyniosło powstanie w 1807 r. Księstwa Warszawskiego. Wówczas to do kraju powrócili nieliczni z kilkudziesięciu tysięcy, którzy przeszli przez te formacje. Wracali jako polityczni bankruci, przepojeni urazami i kompleksami, nie wierzący w pomoc jakiegokolwiek mocarstwa zachodniego. Pomimo tego włączyli się w nurt życia społecznego ${ }^{29}$, a od 2 do 3 tysięcy zdymisjonowanych w różnych okresach legionistów zgłosiło się na wezwanie Dąbrowskiego ${ }^{30}$ do nowo tworzonej armii Księstwa (by następnie wpływać na kształt wojska w Królestwie Polskim). Dodatkowo tysiąc legionistów stanowiło kadry Legii Nadwiślańskiej. „Mimo nienawiści, a nawet pogardy dla Napoleona - zauważał Ryszard Przybylski - powróciło ono (pokolenie legionistów - R. S.) ponownie pod jego sztandary, skoro tylko zaświtała nadzieja restytucji państwa polskiego" ${ }^{31}$. Służąc doświadczeniem organizacyjnym i bojowym, posiadając postępowe poglądy, kontynuowali niegdysiejsi legioniści rozpoczętą co dopiero tradycję walki o wolność i niezależność, a zarazem współtworzyli wzorce nowoczesnego wojska, które okazały się przydatne również w późniejszych okresach zmagań o niepodległość Polski² ${ }^{32}$.

${ }^{28}$ H. Zakrzewski, Mowa na obchodzie pogrzebowym za duszę śp. Jana Henryka Dąbrowskiego, generała jazdy, senatora, wojewody Królestwa Polskiego w kościele katedralnym poznańskim dnia 26 czerwca 1818 miana, Poznań [b.r.], knlb. 3.

29 Zob. S. Kieniewicz, Dramat trzeźwych entuzjastów. O ludziach pracy organicznej, Warszawa 1969, s. 25.

${ }^{30}$ Ks. Łańcucki generałowi Dąbrowskiemu przypisał pierwszeństwo wśród powracających do ojczyzny legionistów: „Ciebie pierwszego na czele powracających dziatek wskrzeszona ujrzała ojczyzna. Tyś pierwszy laurami swemi skronie jej uwieńczył”. J. W. Łańcucki, Kazanie w czasie... pogrzebu ciała śp. Tadeusza Kościuszki..., dz. cyt., s. 34.

31 Przybylski podkreślał, że kiedy znowu przyszedł czas ofiar, w tym pokoleniu na powrót do głosu doszły cnoty obywatelskie, które sprawiały, iż „Cyncynat rzucał pług, rodzinę, dom i zgłaszał się do wojska. Niemal wszyscy skupili się pod sztandarami księcia Józefa Poniatowskiego. Wielu z nich walczyło jeszcze w powstaniu listopadowym". R. Przybylski, Klasycyzm czyli prawdziwy koniec Królestwa Polskiego, Warszawa 1983, s. 251.

32 Zob. J. Pachoński, Koniec Legionów 1806-1807, w: Sprawozdania z posiedzeń Komisji 
Najważniejsze jednak w tym momencie narodowych dziejów było to, że wracali szczęśliwie „na ziemię, która ich wydała i wykarmiła” ${ }^{33}$. To ich heroizm, zdaniem ks. Dłuskiego, wykazany w walkach w różnych częściach świata, pobudził Boga do działania - zesłania Napoleona, by ten wyrwał Polaków ze zniewolenia ${ }^{34}$. Pobudził także ich współrodaków, którzy wcześniej z podziwem patrzyli na tych, co „sławę oręża i imienia polskiego nad Tybrem, Padem, Renem, Dunajem zachowali, jak je, aż w murzyńskie Ameryki kraje, aż na żyzne Nilu brzegi, aż na rozpalone pustyń arabskich piaski zanieśli”. W efekcie, kiedy Napoleon stawał się nadzieją dla Polaków na odzyskanie utraconej wolności „młodsi łącznie ze starszymi walecznością swoją nad Wisłą, Bugiem, Narwią i Preglą, wielkich chwały Bolesławów, Jagiełłów, Zygmuntów, Batorych i Sobieskich wznowili" ${ }^{35}$.

Pośród tych starszych był generał Jan Konopka, o którym ks. Franciszek Godlewski mówił, iż przez 24 lata „służył z honorem i sławą oręża polskiego i z dobrem ojczyzny" ${ }^{36}$. A służył w armii francuskiej, w Legionach generała Dąbrowskiego, w wojsku Księstwa Warszawskiego. Walczył we Włoszech, w kampanii pruskiej,

Oddziału PAN w Krakowie, Kraków 1960, s. 112; A. Zamoyski, Święte szaleństwo..., dz. cyt., s. 188-189. S. Herbert, Żotnierze niepodległości..., dz. cyt., s. 409-411. Ludwik Łętowski, późniejszy biskup krakowski, lubujący się w przekazywaniu plotkarskich informacji, we wspomnieniach pisał o wojsku Księstwa Warszawskiego, że zasilone zostało przez starzejących się niegdysiejszych legionistów Dąbrowskiego, a pułkownikami zostawali ludzie bez bojowego doświadczenia. „Generałów dobrych było więcej - przyznawał Łętowski - ale bódł ich wódz naczelny książę Poniatowski. Dąbrowski go unikał, a Zajączek nie lubił. Lecz to dobro służby nie tamowało". L. Łętowski, Wspomnienia pamiętnikarskie, oprac. H. Barycz, Wrocław 1956, s. 110.

33 Walczący na obczyźnie legioniści, jak podkreślał w kazaniu do nowych polskich rekrutów ks. Szweykowski, powracali do kraju „za temi, którym byli pomocą; powracają i znajdują was nowo uzbrojeni, młodsi synowie Ojczyzny!”. W. Szweykowski, Kazanie do nowo zaciężnych..., dz. cyt., knlb. 6v.

34 „Pola niemieckie, włoskie, hiszpańskie, egipskie i wyspy Ameryki skropione są krwią Polską - perorował ks. Dłuski - ale też za to obfity teraz dla ojczyzny naszej przyniosły owoc, cieszymy się już skutkiem ich heroicznej ofiary, wejrzał Bóg na uciski nasze, zesłał nam Anioła, który nas wyrwał z rąk nieprzyjaciół”. M. Dłuski, Kazanie w dzień uroczystego obchodu..., dz. cyt., s. 12-13.

35 P. Szulczewski, Kazanie pierwsze..., dz. cyt., s. 6. Kajetan Koźmian, charakteryzując atmosferę panującą w Księstwie Warszawskim, wspominał entuzjazm i zapał młodzieży do walki: „Młodzi, wychodzący ze szkół, mniej się cisnęli do biur, do urzędów, najczęściej prosto z ławek szkolnych przesiadali się na konia, w miejsce porzuconych piór, brali szablę do ręki; ten był duch Księstwa, ta żądza znaczenia”. K. Koźmian, Pamiętniki, t. 6, Warszawa 1907, s. 53-54.

${ }^{36}$ F. Godlewski, Kazanie na pogrzebie JW. Jana Konopki generała brygady wojski polskich, barona państwa francuskiego, komandora krzyża Legii Honorowej i kawalera Krzyża Polskiego roku 1814 miesiaca Xbra dnia 29 miane w Zdzięciole, w: Kazania przygodne ks. Franciszka Godlewskiego, t. 4, Wilno 1820, s. 66-67. 
w Hiszpanii, w wojnie z Rosją 1812 r. ${ }^{37}$. W Hiszpanii, o czym wspominał ks. Łańcucki, bił się także rówieśnik Konopki, Feliks Potocki, pułkownik 4-go pułku piechoty Księstwa Warszawskiego ${ }^{38}$. Natomiast do tych młodszych zaliczali się, przywoływani przez ks. Józefa Hipolita Nowowieyskiego w mowie wypowiedzianej w czasie nabożeństwa żałobnego za Katarzynę Małachowską, Ludwik Małachowski szef gwardii cesarza Francuzów oraz jego brat Onufry, odznaczony za waleczność oficer $^{39}$. Należeli do nich również synowie Tekli Łubieńskiej, którzy byli „usługą Wybawcy naszego zajęci”, a co skutkowało tym, że nie zdążyli na pogrzeb matki. Przemawiający na nim ks. Woronicz, martwił się czy w ogóle wieść o zgonie Łubieńskiej dotarła do jej synów nad brzegi Sekwany ${ }^{40}$. Grono to współtworzył Michał Konopka, syn Józefa, byłego łowczego sanockiego, który służył we Włoszech u boku sprzymierzonych wojsk francuskich ${ }^{41}$.

To oni wraz z innymi polskimi żołnierzami czasów napoleońskich, skazanymi na tułaczą dolę, posyłanymi na pola bitew, będą nie tylko reprezentowali swoją ojczyznę, ale staną się przedstawicielami Europy unoszonymi wielką legendą i napędzanymi przekonaniem o potędze ludzkiej woli przemieniającej świat ${ }^{42}$. Kiedy jednak nastanie kres Bonapartego, „boga wojny”, żołnierze ci zostaną osamotnieni, z doświadczeniem życia obozowego, ale bez umiejętności funkcjonowania w warunkach pokojowych. Zauważał to Julian Ursyn Niemcewicz, który oceniając walczących kiedyś pod wodzą cesarza Francuzów, Polaków, pisał: „przyzwyczajeni do

${ }^{37}$ Konopka w Rzeczpospolitej służył w 8 brygadzie kawalerii nadwornej Stanisława Mokronowskiego. Dzielnie walczył w wojnie z Rosją w 1792 r. Brał udział w insurekcji kościuszkowskiej. Przygoda napoleońska skończyła się dla niego w 1812 r., kiedy w Słonimie Rosjanie wzięli go do niewoli i internowali w Chersoniu. Zob. J. Pachoński, Konopka Jan, w: Polski słownik biograficzny [dalej: PSB], t. 13, Wrocław-Warszawa-Kraków 1967-1968, s. 565-567.

38 Zob. J. W. Łańcucki, Kazanie na pogrzebie zwłoków J.W. Włodzimierza na Złotym Potoku hrabi Potockiego, pułkownika artylerii konnej wojska polskiego, kawalera Krzyża Wojskowego, Legii Honorowej, i innych. Miane w kościele katedralnym krakowskim dnia 11 kwietnia 1812, Kraków [b.r.], s. 20-21.

39 Zob. J. Nowowieyski, Mowa w czasie obrzadku pogrzebowego Jaśnie Wielmożnej Jejmości Pani hrabiny Katarzyny z hrabiów Działyńskich Małachowskiej, wojewodziny mazowieckiej, Orderu Krzyża Gwiaździstego damy, ostrołęckiej i wawolnickiej starościny w Borkowicach dnia 12 grudnia 1814 miane, [b.m.r.], s. 22-23.

40 Biblioteka Jagiellońska, rkps 2809, J. P. Woronicz, Na pogrzebie JW z hrabiów Potockich hrabiny Eubieńskiej, t. 5, k. 91v.

${ }^{41}$ Zob. J. Męciński, Kazanie o nauce życia i śmierci, tudzież o dtugach należacych się zmarłym od żyjacych w czasie pogrzebu śp. Józefa Konopki, łowczego sanockiego bywszego, w kościele modlnickim, d. 27 września 1811 roku, Kraków 1811, s. 9.

42 Maria Janion i Maria Żmigrodzka podkreślały, że era napoleońska zbudowała tak mocne u współczesnych przekonanie o ludzkiej możliwości przetwarzania świata, że późniejsze próby zanegowania go nigdy się całkowicie nie udały. Zob. M. Janion, M. Żmigrodzka, Romantyzm i historia, Warszawa 1978, s. 218. 
boju i życia obozowego już nie wiele zdadzą się do rolnictwa i pracy, bodajby inaczej ojczyźnie mogli być pożytecznemi!"’33. I mogli być, bo powstałe z woli Aleksandra I, w ramach przywracania na starym kontynencie dawnego porządku, Królestwo Polskie dawało im taką szansę - służby w armii Królestwa ${ }^{44}$.

Jednym z tych, którzy z niej skorzystali był wspomniany wyżej Jan Konopka. Zwolniony z rosyjskiej niewoli otrzymał dowództwo 1. brygady ułanów. Mówił o tym z patosem ks. Godlewski: „Już dusza jego zatopiła się w słodyczy tej nadziei, iż wskrzeszoną i do pierwszego stopnia chwały przywróconą ujrzy ojczyznę, iż nieodrodny od innych współtowarzyszów broni dobrze myślących, wypłaci się jej z należnego długu chociażby ofiarą życia, iż okaże w całej działalności wierność swoją, iż odpowie skutecznie dobroczynnym zamiarom wielkiego Monarchy i jego położonemu w sobie zaufaniu, iż na resztę unikczemni wszelkie (jeśli mogły być jakie) powątpiewania o jego nieskażonej miłości ojczyzny"45. Czas jednak pokaże, że to nie służba w wojsku Królestwa Polskiego zapewniała Konopce i jemu podobnym miano miłośników ojczyzny, ale właśnie walka pod wodzą Napoleona. Jej uczestnicy bowiem dawali swym rodakom, poranionym klęskami, zniewolonym, poczucie wielkości. Dlatego też ich bohaterskie dokonania, odpowiadając na zapotrzebowanie społeczne, staną się własnością ogółu. Ten zaś dostrzeże w żołnierzach doby napoleońskiej dziedziców staropolskiego męstwa i bojowników narodowej sprawy, których wzorcowym reprezentantem, promowanym również przez kaznodziejów, stanie się książę Józef Poniatowski.

W ocenie Jerzego Skowronka, książę Józef, przez swe bohaterstwo, determinację i ofiarę z życia, „symbolizował dramatyczną epokę polskich ofiarnych dążeń i polskich katastrof, a zarazem w jakiejś mierze podnióst swoim imieniem i opromienił naród, któremu u schyłku XVIII stulecia brakło, w tragicznej narodowej

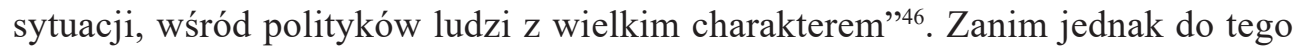
doszło, bratanek ostatniego króla szlacheckiej Rzeczpospolitej, adiutant cesarza Józefa II, generał broniący dzieła Sejmu Czteroletniego, insurgent kościuszkowski, po ostatnim rozbiorze Polski wiódł życie niezapowiadające, że w przyszłości stanie się symbolem narodowym. Księciu Pepi, reprezentantowi wybornie bawiącej się młodzieży w warszawskim Pałacu Pod Blachą, już wcześniej zarzu-

43 J. U. Niemcewicz, Pamiętniki (1809-1820), t. 2, (1813-1820), Poznań 1871, s. 123.

${ }^{44} \mathrm{O}$ trudnej sytuacji, bojowych nastrojach i mężnym duchu żołnierzy uformowanej armii Królestwa Polskiego wspominał, w specyficznym dla siebie stylu, Ludwik Łętowski: „Wojsko tak zwane Królestwa Polskiego był to żołnierz polski, ale nie wojsko polskie. Wymusztrowane jak lalka tańcowało po saskim dziedzińcu, oddane na zabawę człowiekowi (Wielkiemu Księciu Konstantemu - R.S.), co ze zniewagi jego robił sobie zasługę i sławę. [...] Wszystko co z dołu wołało bić się i bić tylko, i biło się, i byłoby pobiło, lecz nie umiał temu kto przewodzić, co byłoby na równi z tym duchem, co ożywia naszego żołnierza”. L. Łętowski, Wspomnienia..., dz. cyt., s. 111-112.

${ }^{45}$ F. Godlewski, Kazanie na pogrzebie JW. Jana Konopki..., dz. cyt., s. 69.

46 J. Skowronek, Ksiązę Józef Poniatowski, Wrocław 1984, s. 261. 
cano zdradę, obwiniano o uleganie wujowi, sprawcy nieszczęść ojczyzny - królowi Stanisławowi Augustowi, oskarżano o kierowanie się interesem rodzinnym i korzyścią swojej warstwy społecznej. Teraz, tj. w okresie pruskiego panowania w Warszawie, wytykano mu uleganie cudzoziemszczyźnie i obojętność na sprawy krajowe. Tak wspominał ten czas w życiu księcia, bez tajenia czegokolwiek, hrabia Fryderyk Skarbek: „Mało się troszczył o losy kraju, nie dbając o popularność i dobre imię u szlachty, przejęty sposobem widzenia cudzoziemskim i nie myśląc nawet o potrzebie utrzymania ducha narodowego, prowadził książę Józef życie nieczynne, rozkoszom i zabawom wyłącznie poświęcone, a to jeszcze pod wpływem skapryszonej Francuski, wraz z mężem przy niegdym kochanku swoim mieszkającej" $"$.

Przemiana w postawie Poniatowskiego nastąpiła w dobie Księstwa Warszawskiego. Jego ówczesne zaangażowanie - objęcie urzędu ministra wojny i stanowiska naczelnego wodza Wojsk Polskich oraz pomyślne dowodzenie w wojnie z Austrią 1809 r. sprawiły, iż współcześni zaczęli dostrzegać w nim prawość charakteru, bezinteresowność, wysokie poczucie osobistej godności, kontynuatora i wskrzesiciela dawnych polskich tradycji wojskowych, znajdując ostatecznie potwierdzenie swojej obserwacji w wiernym trwaniu księcia przy Napoleonie, aż do tragicznego finału w nurtach Elstery ${ }^{48}$. Wśród tych współczesnych był Kajetan Koźmian, który zostawił następującą charakterystykę Poniatowskiego: „Był w nim prawdziwy ideał rycerza z wszystkiemi wdziękami, z całym urokiem zacności, szlachetności, uprzejmości, męstwa, dobroci, a zarazem godności, które się w jego wejrzeniu, w jego twarzy, w jego każdym ruchu malowały. Nie dziw więc, że w młodości był psuty przez kobiety, a w męskim wieku miał szacunek, miłość i uwielbienie współziomków, bo na nie zarobić umiał. Jako minister wojny nie był na swojem miejscu, do pracy umysłowej i mozolnej nie był zdolny, dla niego koń, szabla, plac boju, lub przynajmniej obroty wojska były najulubieńszem zatrudnieniem, tego się uczył za młodu w szkole rycerskiej, do tego w służbie austriackiej w młodzieńczym wieku nawykł"49. To zaś

47 Pamiętniki Fryderyka hrabiego Skarbka, oprac. P. Mysłakowski, Warszawa 2009, s. 69.

48 Zob. J. Skowronek, Poniatowski Józef Antoni, w: PSB, t. 27, Wrocław-Warszawa-Kraków-Gdańsk-Łódź 1983, s. 428-436. Zdaniem Jerzego Skowronka pozostanie księcia Józefa przy Bonapartym, pomimo oferty przejścia na stronę cara Aleksandra I, było efektem dojrzewania w nim poczucia odpowiedzialności politycznej za losy kraju i narodu. Odrzucenie propozycji cara nie było motywowane irracjonalnym wewnętrznym przymusem zachowania honoru, ani też osobistym przylgnięciem do cesarza Francuzów. Jego decyzja dowodziła za to ,zrozumienia tragizmu położenia sprawy polskiej - podsumowywał Skowronek - i w pełni uzasadnionego politycznie i etycznie wyboru między pełną kapitulacją, a rozpaczliwym acz usprawiedliwionym szukaniem u boku Napoleona jeszcze jednej, ostatniej szansy dla sprawy polskiej”. J. Skowronek, Honor czy jedyna szansa? Polityczne dylematy Józefa Poniatowskiego w 1813 r., w: Francja-Polska XVIII-XIX w. Studia z dziejów kultury i polityki poświęcone Profesorowi Andrzejowi Zahorskiemu w sześćdziesiąta rocznicę urodzin, Warszawa 1983, s. 138-141.

49 K. Koźmian, Pamiętniki, t. 4, Warszawa 1907, s. 72-73. 
odmienione od wcześniejszego postrzeganie księcia Józefa było tylko wstępem do tego, co się wydarzyło po jego śmierci.

Ginąc w „bitwie narodów” pod Lipskiem w 1813 r., królewski bratanek w powszechnym odbiorze społecznym uznany zostanie za bohatera; narodowego herosa, którego postać należało utrwalić w pozytywnej legendzie. Dlatego też jego chwalebny zgon zacznie być traktowany jako symbol śmierci ojczyzny, a on sam uznany zostanie za spadkobiercę jej minionej wielkości i trwałości niepodległego bytu; za ucieleśnienie najwznioślejszych cnót żołnierskich; obrońcę narodowego honoru, będącego konsekwencją rycerskiej powinności; za kwintesencję polskości; ideał poświęcenia się dobru powszechnemu i krajowemu; uosobienie najszczytniejszych wartości moralnych narodu; przykład umiłowania ojczyzny i rodaków; reprezentanta nowej duchowej ojczyzny, której zaborcy nie zdołają zniweczyć; wzór skromności i szlachetności. Ubierana w te przymioty postać księcia Józefa miała za zadanie łączyć polskie społeczeństwo, pomagać byłym zwolennikom Napoleona odnajdywać się w nowej rzeczywistości politycznej, przekonywać, że służba zbiorowości może zaowocować moralnym odrodzeniem ${ }^{50}$. Rezultatem zaś tego zabiegu była sakralizacja bohatera spod Lipska i jego legendy, w której istotną rolę odegrały nabożeństwa żałobne. Cała ich seria rozłożona w czasie, organizowanych we wszystkich trzech zaborach, w większych i mniejszych miastach, w świątyniach różnych wyznań, włącznie z lożą masońską Braci Zjednoczonych, której poległy książę był honorowym członkiem, zapoczątkowały kultu Poniatowskiego. W jego ramach doczesne szczątki księcia Józefa nabierały cech relikwii narodowej. W kulcie tym równocześnie cześć składano wszystkim żołnierzom walczącym o wolność narodu. Dokonywano podsumowania niepodległościowych dążeń pierwszych dwóch dziesięcioleci rozbiorowych.

Pierwotnie zwłoki napoleońskiego marszałka złożono w krypcie kościoła św. Jana w Lipsku (26 listopada 1813 r.). Następnie po uzyskaniu zgody Aleksandra I zostały przeniesione do kościoła Świętego Krzyża w Warszawie (9-10 września 1814 r.), by ostatecznie 23 lipca 1817 r. spocząc w katedrze wawelskiej. W organizowanych wtenczas uroczystościach brali udział reprezentanci wszystkich warstw społecznych (osoba księcia, miała łączyć wszystkich obywateli z trzech zaborów, niezależnie od wyznania i pochodzenia), a także przedstawiciele władz rosyjskich i wojsko (zaborcom zależało na nadaniu rodzącemu się kultowi charakteru państwowego, a nie narodowego). Fundusze na ich organizację pochodziły przede wszystkim ze zbiórek (tak jak na budowę pomnika), co niewątpliwie powstający mit księ-

50 Zob. I. Węgrzyn, Książę Józef Poniatowski. Polskość w pułapce honoru, w: Książę Józef Poniatowski w kulturze i edukacji, red. Z. Budrewicz, T. Budrewicz, M. Chrobak, Kraków 2014, s. 31-44; J. Cieślikowski, Ksiązę Józef Poniatowski. Stereotypowy obraz bohatera, „Acta Universitatis Wratislaviensis. Prace Literackie” 11-12 (1970), nr 131, s. 215-259; J. Paluszewski, Legenda literacka Księcia Józefa Poniatowskiego, Pruszków 2006, s. 7-8, 33-53, 61-65, 75; M. Janion, M. Żmigrodzka, Romantyzm..., dz. cyt., s. 274-286, 291-292. 
cia Józefa mocniej zakorzeniało w świadomości społecznej ${ }^{51}$, której kształt nadawali również kaznodzieje przemawiający w trakcie tych żałobnych uroczystości.

W ich wystąpieniach Poniatowski lśnił wszelakimi cnotami, prezentował nowy typ bohatera narodowego, zdobywającego rycerską sławę i poważanie ogółu poprzez osobiste zasługi, a nie rodzinne koneksje, oddającego życie w akcie ekspiacji za grzechy zbiorowości. Takim był książę w kazaniu ks. Adama Prażmowskiego, wówczas prepozyta kolegiaty warszawskiej, wygłoszonym 19 listopada 1813 r. w kościele Świętego Krzyża w Warszawie. Kaznodzieja przypisywał zmarłemu niepospolite męstwo, rzadko spotykaną roztropność i ujmującą łagodność. Z tym, że męstwo to nie było bezmyślną brawurą, narażaniem się na niepotrzebną śmierć, ale umiejętnością jej unikania, kiedy zachodziła taka potrzeba. „Takim się zawsze okazywał w wielorakich bitwach Książę Poniatowski. Widzieli mieszkańcy tej stolicy - nawiązywał Prażmowski do wydarzeń z 1809 r. - gdy siedem razy liczniejszego od murów jej odpierał nieprzyjaciela, a po kilkunastogodzinnej walce zwycięstwo uczyniwszy wątpliwym, u wspaniałego przeciwnika sobie dozgonny szacunek, wojsku zaszczyt, miastu korzystne uzyskał warunki" ${ }^{52}$. Roztropność z kolei polegała na umiejętnym dowodzeniu wojskiem. Stojąc bowiem na czele niezaprawionego w bojach żołnierza, a mając przed sobą kilkakrotnie silniejszego i bardziej doświadczonego w walce przeciwnika, okazał dowódczy kunszt - „Usuwa się, ale bez trwogi, odpiera natarczywość bez popędliwości, zaprawia swoich do bitew bez wystawiania na zgubę, uprowadza wreszcie mil kilkadziesiąt bez szwanku"s33. Odnośnie do łagodności, to miało ją wyrażać pogodne usposobienie księcia, bezpośredniość w obcowaniu z podwładnymi, troska o cierpiących. Dlatego też, kiedy po zajęciu Krakowa w 1809 r. jego żołnierzy dziesiątkowała zaraza, narażając własne życie, odwiedzał chorych, pocieszał ich, „o wygodę troskliwie się pytał, roznoszeniu pokarmów sam był przytomny”54. To wszystko oczywiście znamionowało cnotliwego wodza, którego Prażmowski równocześnie prezentował jako rzetelnego obywatela, wyróżniającego się miłością do ojczyzny i niezachwianą dla niej wiernością. Objaśniając to ostatnie kaznodzieja dokonał nie lada wyczynu

51 Zob. M. Żbikowska, Nabożeństwo żałobne po śmierci Józefa Poniatowskiego. Rytuat a mit, w: Francja-Polska..., dz. cyt., s. 178-182; G. P. Bąbiak, Funeralia narodowe. Pogrzeby patriotyczne Polaków w czasach niewoli, Warszawa 2016, s. 63-70.

52 A. Prażmowski, Kazanie na obchodzie żałobnej pamięci J.O. Książęcia Józefa Poniatowskiego ministra wojny i naczelnego wodza wojska Księstwa Warszawskiego miane w kościele warszawskim S. Krzyża dnia 19 listopada 1813, Warszawa 1813, s. 8. Prażmowski swoje kazanie wygłaszał w obecności rosyjskiej generalicji, m.in. generała-gubernatora Wasyla Łanskoja oraz zastępcy przewodniczącego Rady Najwyższej Tymczasowej Księstwa Warszawskiego Nikołaja Nowosilcowa. Zob. H. Mościcki, Pozgonna cześć dla Księcia Józefa. Pogrzeb - pomniki - pieśni i legenda, Warszawa [b.r.], s. 10-11.

53 A. Prażmowski, Kazanie na obchodzie żałobnej pamięci J.O. Książęcia Józefa Poniatowskiego..., dz. cyt., s. 11.

54 A. Prażmowski, Kazanie na obchodzie żałobnej pamięci J.O. Książęcia Józefa Poniatowskiego..., dz. cyt., s. 12. 
- połączył posłuszeństwo i uszanowanie obcej władzy w okresie beztroskiego życia w Pałacu pod Blachą z przygotowywaniem wojska na wyprawę moskiewską i trwaniem aż do końca przy Napoleonie ${ }^{55}$. A na koniec, prepozyt kolegiaty warszawskiej, uczynił ze zmarłego księcia wzorowego syna Kościoła: „widzieliśmy go obecnego świętym wiary naszej tajemnicom z przykładną skromnością, szanującego jej obrzędy. Nie skaził ust jego mniej przystojne szyderstwa, ani wymierzone przeciw religii pociski" ${ }^{56}$.

Ten hagiograficzny wizerunek Józefa Poniatowskiego został wzmocniony 9-10 września $1814 \mathrm{r}$. Wtedy to przewiezione z Lipska ciało księcia uroczyście złożono w podziemiach kościoła Świętego Krzyża w Warszawie. Program uroczystości opracował naczelny wódz wojsk rosyjskich, feldmarszałek Michaił Barclay de Tolly wraz z polskimi generałami. Mszę żałobną sprawował bp Franciszek Zambrzycki, a kazanie wygłosił ks. Woronicz, podówczas dziekan kapituły warszawskiej ${ }^{57}$. W nim ten wytrawny kaznodzieja przypominał o pokrewieństwie honorowanego zmarłego z Jagiellonami, wskazywał na posiadane cnoty narodowe, zachęcając odbiorców swojego kazania do kultywowania tychże cnót. Rozprawiał więc Woronicz o zaprzysiężonej władcom (w tym Napoleonowi) i ojczyźnie wierności, która brała się z nieskalaności księcia Józefa. „Przywiedźcie na pamięć ową jego czystą i szlachetną otwartość duszy - wzywał kaznodzieja uczestników nabożeństwa - w której wszystko, jako w przezroczystej krynicy, przejrzyć i rozpatrzyć można było. Nie cierpiał on tej półgębnej zawiści, niewolniczym służebnikom ulubionej, którą ci zwodziciele ufności podług powiewu obłudy szafują. Nie uląkł się w zbiegu osobistej wdzięczności dać pierwszeństwa długowi ojczyzny. Dusza jego zawsze jasna jak słońce, z żadnym ustroniem pokątnym, z żadną kryjówką ciemności zgodzić się nie mogła" ${ }^{98}$. W tej też nieskalaności swoje źródło miała mieć dobroć, którą książę okazywał ubogim mieszkańcom Warszawy oraz cierpiącym niedostatek, rannym i okaleczonym żołnierzom, wspierając ich materialnie. Poza tym Woronicz zrównywał Poniatowskiego z niegdysiejszymi rodzimymi hetmanami i wojownikami, przypisywał zasługę odrodzenia wojska polskiego, ukazywał wielkość jego wojennych czynów, przypominał o przestrzeganiu etosu rycerskiego ${ }^{59}$, czynił obroń-

55 A. Prażmowski, Kazanie na obchodzie żałobnej pamięci J.O. Książęcia Józefa Poniatowskiego..., dz. cyt., s. 15-16.

56 A. Prażmowski, Kazanie na obchodzie żałobnej pamięci J.O. Książęcia Józefa Poniatowskiego..., dz. cyt., s. 22.

57 Kazimierz Brodziński pisał o tym, iż Woronicz doprowadził słuchaczy do łez: „Płakało na tem kazaniu rycerstwo, lud i panowie" (zob. H. Mościcki, Pozgonna cześć dla Księcia Józefa..., dz. cyt., s. 50). Kazanie to w odbitkach sprzedawano po 2 zł. Dochód ze sprzedaży przeznaczono na „wsparcie ubogich, sierot i wdów wojskowych” (zob. G. P. Bąbiak, Funeralia narodowe..., dz. cyt., s. 67).

58 J. P. Woronicz, Kazanie na pogrzebie... Józefa Poniatowskiego..., dz. cyt., s. 225; zob. A. Jougan, Ks. prymas Woronicz, cz. 1, Lwów 1908, s. 155-156; cz. 2, Lwów 1908, s. $143-149$.

59 Woronicz nawiązywał do rozkazu jaki wydał swoim żołnierzom książę Józef, zakazujące- 
cą bezbronnych ludów, a zarazem zaznaczał, że wraz z jego śmiercią zawiedzione zostały nadzieje Polaków na odzyskanie ojczyzny. Zawód ten kaznodzieja zawarł w dramatycznych pytania: „Takież ja tobie przeznaczenie przed lat ośmiu zapowiadał, kiedyś odkopane orły ojczyste pierwszy do nowych turniejów świadomą ręką podnosił? I więc, że cała twoja wielkość, świetność i zasługa w tej się garstce rozsypanych popiołów zamyka?" ${ }^{60}$. Na tej przejmującej interrogacji Woronicz jednak nie poprzestał. Natychmiast bowiem wznawiał $\mathrm{w}$ dawnych podkomendnych księcia nową nadzieję, przekonując o owocności ofiary ich wodza. Ta w ostatecznym rozrachunku miała ich zwrócić ku Bogu, ugruntować w pewności co do stałości jego panowania i opieki oraz utwierdzić w poczuciu przeznaczenia do niebieskiej nagrody. „Wznieście się za wodzem waszym wyżej tych gwiazd i słońców gorejących wzywał żałobników Woronicz - a poznajcie tam wiekuistego Pana ojców waszych, który się jeden z tronem swoim nigdy nie zachwieje. On jeden każdą kroplę znoju waszego na szali swojej przeważył. On sam chmury świszczących śmierci między wami rozprowadzał i każdej kuli przykazał, kogo z was pominąć miała. On was po zgruchotanym okręcie zawiedzionych obietnic jeszcze na tej chwiejącej się łódce z powiewną banderą nadziei na łono nasze powraca. Mało na tym, On w księgach swoich wasze imiona, zasługi, a nawet i same chęci dobrego wiernie i po bożemu do zgody zapisał. On wam poczesne sadowiska obok tronu swojego porozstawiał" ${ }^{1}$. On też, o co w zakończeniu kazania prosił kościelny mówca, miał wejrzeć na ofiarę poległego w bitwie księcia i umieścić na zawsze w jego grobie wszystkie dotychczasowe nieszczęścia Polaków. „Niech ten dzisiejszy pogrzeb - zwracał się z błaganiem do Boga kaznodzieja - w dziejach naszych pamiętny, będzie razem wszystkich naszych łez i ucisków nigdy nie odwalonym grobowiskiem" ${ }^{2}$. Prośba ta nie został jednak wysłuchana, ponieważ po trzech latach od warszawskiego pogrzebu księcia Józefa, urządzono kolejny, tym razem na Wawelu. Powróciło więc wspomnienie „łez i ucisków", ale co istotne, przenosiny do Krakowa jeszcze bardziej przyczyniły się do wzmocnienia legendy Poniatowskiego, jako przykładowego narodowego bohatera.

Kiedy w lipcu 1817 r. Warszawa żegnała doczesne szczątki Józefa Poniatowskiego, ks. Szaniawski w przemowie wygłoszonej z tej okazji podkreślał z dumą, iż zmarły, krewniak „ukochanego naszego króla Stanisława Augusta”, „ozdoba narodu”, spocznie wśród władców Polski, powiększając wawelski zbiór „starożytnej wielkości naszej”. Równocześnie Szaniawski dziękował carowi Aleksandrowi I za pozwolenie sprowadzenia zwłok najpierw do Warszawy, a następnie przeniesienia do Krakowa, „,smutnego siedliska ojców naszej ojczyzny”63. Tym samym przez miej-

go im udziału w grabieży Moskwy w 1812 r. oraz do karnego przemarszu wojsk polskich pod dowództwem Poniatowskiego przez Saksonię w 1813 r. J. P. Woronicz, Kazanie na pogrzebie... Józefa Poniatowskiego..., dz. cyt., s. 227.

60 J. P. Woronicz, Kazanie na pogrzebie... Józefa Poniatowskiego..., dz. cyt., s. 229.

61 J. P. Woronicz, Kazanie na pogrzebie... Józefa Poniatowskiego..., dz. cyt., s. 230.

62 J. P. Woronicz, Kazanie na pogrzebie... Józefa Poniatowskiego..., dz. cyt., s. 233.

63 Zob. F. K. Szaniawski, Przemowa przy wyprowadzeniu zwłok Księcia Józefa Poniatow- 
sce ostatecznego pochówku książę Józef stawał się równy królom, a Wawel mauzoleum narodowym, przestrzenią dla Polaków świętą ${ }^{64}$.

W katedrze wawelskiej trumnę ze zwłokami księcia złożono 23 lipca $1817 \mathrm{r}$. w grobie, który przygotował dla siebie król Stanisław August. Znowu, tak jak to było w Warszawie, narodowego bohatera uhonorował Jan Paweł Woronicz. Będąc już wtedy biskupem krakowskim sprawował Mszę żałobną. Płomienne kazanie wygłosił ks. Łańcucki. Trumnę do grobu znieśli oficerowie. Przed otwartym grobowcem zatrzymał ich bp Woronicz, by pobłogosławić grzebane szczątki ${ }^{65}$.

W swoim wystąpieniu Łańcucki zrównywał zasługi Poniatowskiego dla ojczyzny z godnością królewską. W taki oto sposób tłumaczył ulokowanie księcia wśród władców Polski: ,godnym stał się wspólnictwa z wami, w tem miejscu, gdzie blask tronu, blasku zasługi umniejszać nie może" ${ }^{66}$. Następnie kaznodzieja wspomniał o babce księcia Józefa, skoligaconej z Jagiellonami, dziadku Stanisławie współpracowniku Karola XII oraz ojcu Jędrzeju służącym w wojsku austriackim, by ostatecznie skupić się na osobie zmarłego. Czyniąc to, archiprezbiter mariacki odtworzył przebiegł życia Poniatowskiego - od wstąpienia za przykładem ojca w szeregi armii rakuskiej, aż po śmierć w nurtach Elstery, podkreślając jednocześnie jego znaczenie dla ojczyzny. Ukazywał go przy tym jako wytrawnego wodza, przezornego w prowadzeniu bitew, dbałego o żołnierzy (którego za cnoty i wysiłek włożony w ocalenie narodu docenił rosyjski imperator ${ }^{67}$ ), miłośnika ojczyzny. „Jej tylko nieprzyjaciół orężem swym ścigał, swoich albo nie miał, albo ich dobrocią i łaskami pokonywał. Taki człowiek, taki bohatyr - zastanawiał się Łańcucki - nie powinien że był bydź wyjętym z kolei losów ludzkich, które pocieszać i zasmucać, raz łzy radości i pociehy, drugi raz żalu i rozpaczy wyciskać zwykły!”68. To jednak, że ten idealny bohater nie został wyłączony spod praw zmiennych ludzkich losów, nie oznaczało kresu

skiego z kościoła Świętego Krzyża w Warszawie, do grobu w Krakowie 17. lipca r. 1817, w: Kazania..., dz. cyt., s. 252-253, 254. Decyzja Aleksandra I miała na celu wzmocnienie prorosyjskich sympatii w polskim społeczeństwie, a zarazem szerzej otworzyła podwoje wawelskiej katedry. Odtąd, oprócz grobów królewskich, miejsce wiecznego spoczynku znajdą w niej persony ważne w życiu narodu - bohaterowie i wieszczowie. Zob. G. P. Bąbiak, Funeralia narodowe..., dz. cyt., s. 68.

${ }^{64}$ Zob. G. P. Bąbiak, Funeralia narodowe..., dz. cyt., s. 69-70; M. Sadlik, Tu nie mowy lecz malarskiego trzeba pędzla (...) - wokół dwóch krakowskich pogrzebów: księcia Józefa Poniatowskiego i Jana Pawła Woronicza, w: Narodziny Rzeczpospolitej Krakowskiej. Relacje - obrazy - wspomnienia, red. M. Stankiewicz-Kopeć, T. Budrewicz, Kraków 2016, s. $123-128$.

65 Zob. H. Mościcki, Pozgonna cześć dla Księcia Józefa..., dz. cyt., s. 52-62.

66 J. W. Łańcucki, Kazanie podczas religijnych obrzędów przy złożeniu w grobie królów polskich zwłoków Józefa Księcia Poniatowskiego naczelnego wodza wojsk polskich, ministra wojny, marszatka państwa francuskiego, wielu orderów kawalera. W kościele katedralnym krakowskim, dnia 23 lipca 1817 roku miane, [b.m.r.], s. 7.

67 Zob. J. W. Łańcucki, Kazanie..., dz. cyt., s. 15-16.

68 J. W. Łańcucki, Kazanie..., dz. cyt., s. 23. 
jego sławy. Wręcz przeciwnie, krakowski mówca słusznie przewidywał, iż czas tylko będzie utwierdzał ową sławę. Dla przyszłych pokoleń grób księcia Józefa, jak głosił z niezachwianym przekonaniem krakowski mówca, ,zacznie bydź świątynią, gdzie popioły jego nauczać będą długie pokolenia Polaków cnoty i miłości ojczyzny; grób! gdzie wszystko śmiertelności grozi, a jemu nieśmiertelność zaręcza"69.

Słowa te się ziściły. Postać i losy księcia Józefa Poniatowskiego, obrosły legendą czasów napoleońskich oraz sławą pierwszego męczennika w walce o narodową niepodległość, uosabiając całe, walczące o niepodległość pokolenie. Stały się też inspiracją dla następnych generacji walczących o wolność Polski, zwłaszcza dla powstańców listopadowych. A to oznaczało, iż kolejne zmagania o własne, niezależne od nikogo państwo, były kontynuacją walk „za wolność naszą i waszą”. Były zarazem potwierdzeniem, że odmiana narodowego losu, o co bili się zapatrzeni w przykład Bonapartego Polacy, nie dokonała się ani prosto, ani szybko, za to niezmiennie od bojowników wymagała militarnego wysiłku i daniny krwi.

\section{BIBLIOGRAFIA}

\section{Źródła rękopiśmienne:}

\section{Biblioteka Jagiellońska:}

Rkps 2809, Woronicz J.P., Na pogrzebie JW z hrabiów Potockich hrabiny Łubieńskiej, t. 5.

\section{Źródła drukowane:}

Dłuski M., Kazanie w dzień uroczystego obchodu imienin Najjaśniejszego i Najpotężniejszego Napoleona Wielkiego Cesarza Francuzów, króla włoskiego, protektora Ligi Reńskiej, oswobodziciela Polski miane w kościele katedralnym wileńskim dnia 15 augusta 1812 roku, Wilno [b.r.].

Falkowski J., Mowa do ludu w czasie obchodu uroczystości dziękczynienia Bogu za zwycięstwo W. Napoleona otrzymane pod Rohr, miane dnia 8 maja 1809 w Szczucinie, [b.m.r.].

Godlewski F., Kazanie na pogrzebie JW. Jana Konopki generała brygady wojski polskich, barona państwa francuskiego, komandora krzyża Legii Honorowej i kawalera Krzyża Polskiego roku 1814 miesiaca Xbra dnia 29 miane w Zdzięciole, w: Kazania przygodne ks. Franciszka Godlewskiego, t. 4, Wilno 1820, s. 60-85.

Jaroński F., Mowa na dzień obchodu imienin Najjaśniejszego Fryderyka Augusta króla saskiego, książęcia warszawskiego, dnia 3go sierpnia 1810 roku w kościele katedralnym krakowskim miana, Kraków [b.r.].

69 J. W. Łańcucki, Kazanie..., dz. cyt., s. 29-30. 
Koźmian K., Pamiętniki, t. 4, Warszawa 1907.

Koźmian K., Pamiętniki, t. 6, Warszawa 1907.

Łańcucki J. W., Kazanie na pogrzebie zwłoków J.W. Włodzimierza na Złotym Potoku hrabi Potockiego, putkownika artylerii konnej wojska polskiego, kawalera Krzyża Wojskowego, Legii Honorowej, i innych. Miane w kościele katedralnym krakowskim dnia 11 kwietnia 1812, Kraków [b. r.].

Łańcucki J. W., Kazanie podczas religijnych obrzędów przy złożeniu w grobie królów polskich zwłoków Józefa Księcia Poniatowskiego naczelnego wodza wojsk polskich, ministra wojny, marszałka państwa francuskiego, wielu orderów kawalera. W kościele katedralnym krakowskim, dnia 23 lipca 1817 roku miane, [b.m.r.].

Łańcucki J. W., Kazanie w czasie uroczystych obrzędów pogrzebu ciała śp. Tadeusza Kościuszki w kościele katedralnym krakowskim dnia 23 czerwca 1818, Kraków [b.r.].

Łętowski L., Wspomnienia pamiętnikarskie, oprac. H. Barycz, Wrocław 1956.

Męciński J., Kazanie o nauce życia i śmierci, tudzież o dtugach należacych się zmartym od żyjacych $w$ czasie pogrzebu śp. Józefa Konopki, łowczego sanockiego bywszego, w kościele modlnickim, d. 27 września 1811 roku, Kraków 1811.

Niemcewicz J.U., Pamiętniki (1809-1820), t. 2, (1813-1820), Poznań 1871.

Nowowieyski J., Mowa w czasie obrządku pogrzebowego Jaśnie Wielmożnej Jejmości Pani hrabiny Katarzyny z hrabiów Dziatyńskich Małachowskiej, wojewodziny mazowieckiej, Orderu Krzyża Gwiaździstego damy, ostrołęckiej i wąwolnickiej starościny w Borkowicach dnia 12 grudnia 1814 miane, [b.m.r.].

Pamiętniki Fryderyka hrabiego Skarbka, oprac. P. Mysłakowski, Warszawa 2009.

Prażmowski A., Kazanie na obchodzie żałobnej pamięci J.O. Ksiązęcia Józefa Poniatowskiego ministra wojny i naczelnego wodza wojska Księstwa Warszawskiego miane w kościele warszawskim S. Krzyża dnia 19 listopada 1813, Warszawa 1813.

Szaniawski F. K., Mowa na nabożeństwie żałobnym za duszę śp. Jana Henryka Dabrowskiego 17. czerwca roku 1818 w kościele Sgo Krzyża w Warszawie, w: Kazania, t. 3, Warszawa 1820, s. 323-337.

Szaniawski F. K., Przemowa przy wyprowadzeniu zwłok Księcia Józefa Poniatowskiego z kościoła Świętego Krzyża w Warszawie, do grobu w Krakowie 17. lipca r. 1817, w: Kazania, t. 3, Warszawa 1820, s. 251-255.

Szulczewski P., Kazanie pierwsze miane $w$ czasie żałobnego nabożeństwa za poleglych w sprawie ojczyzny braci naszych Polaków w kościele WW. OO. Bernardynów dnia 6 października roku 1808, w: Dwa kazania żałobne, Rawicz 1809, s. $3-16$.

Szweykowski W., Kazanie do nowo zaciężnych obrońców ojczyzny, miane wśrzód czy wśrzód? uroczystości poprzedzajacej przysięge wojskowa korpusu JW. Generała Woyczyńskiego, w kościele katedralnym płockim, dnia 8 marca roku 1807, [b.m.r.].

Woronicz J. P., Kazanie na pogrzebie sprowadzonych do Warszawy zwłoków śp. J[aśnie] O[świeconego] ksiażęcia Józefa Poniatowskiego [1814], w: Jan Pawet 
Woronicz. Pisma wybrane, oprac. M. Nesteruk, Z. Rejman, Wrocław-WarszawaKraków 2002, s. 216-233.

Woronicz J. P., Kazanie przy pierwszym otwarciu Sejmu Głównego Księstwa Warszawskiego miane w kościele katedralnym warszawskim, dnia 10. miesiaca marca roku 1809, Warszawa 1809.

Woronicz J. P., Kazanie przy uroczystym poświęceniu orłów i choragwi polskich wojsku narodowemu nadanych [1807], w: Jan Pawet Woronicz. Pisma wybrane, oprac. M. Nesteruk, Z. Rejman, Wrocław-Warszawa-Kraków 2002, s. 175-197.

Zakrzewski H., Mowa na obchodzie pogrzebowym za duszę śp. Jana Henryka Dabrowskiego, generała jazdy, senatora, wojewody Królestwa Polskiego w kościele katedralnym poznańskim dnia 26 czerwca 1818 miana, Poznań [b.r.].

\section{Opracowania:}

Banaszak M., Michat Dluski, w: Stownik polskich teologów katolickich, t. 1, Warszawa 1981, s. 399-400.

Bąbiak G. P., Funeralia narodowe. Pogrzeby patriotyczne Polaków w czasach niewoli, Warszawa 2016.

Cieślikowski J., Ksiażę Józef Poniatowski. Stereotypowy obraz bohatera, „Acta Universitatis Wratislaviensis. Prace Literackie" 11-12 (1970), nr 131, s. 215-259.

Grochowski L., Ksiadz Jakub Falkowski (1775-1848) - pionier nauczania dzieci głuchych na ziemiach polskich. $Z$ dziejów dziedzictwa edukacyjnego ojców pijarów, w: Wkład pijarów do nauki i kultury w Polsce XVII-XIX wieku, red. I. Stasiewicz-Jasiukowa, Warszawa-Kraków 1993, s. 501-527.

Hamanowa M., Obraz śmierci w kazaniach z czasów Księstwa Warszawskiego, „Napis" 5 (1999), s. 169-175.

Hamanowa M., Treści społeczne w kazaniach z okresu Księstwa Warszawskiego, w: Historia, idee, polityka. Ksiega dedykowana Profesorowi Janowi Baszkiewiczowi, red. F. Ryszka, Warszawa 1995, s. 201-209.

Herbert S., Żotnierze niepodległości, w: Polska w epoce oświecenia. Państwo-społeczeństwo-kultura, red. B. Leśnodorski, Warszawa 1971, s. 392-411.

Janion M., Żmigrodzka M., Romantyzm i historia, Warszawa 1978.

Jougan A., Ks. prymas Woronicz, cz. 1, Lwów 1908.

Jougan A., Ks. prymas Woronicz, cz. 2, Lwów 1908.

Kieniewicz S., Dramat trzeźwych entuzjastów. O ludziach pracy organicznej, Warszawa 1969.

Kumor B., Łańcucki Józef Wincenty, w: Stownik polskich teologów katolickich, t. 2, Warszawa 1982, s. 549-550.

Kumor B., Prażmowski Adam Michał, w: Słownik polskich teologów katolickich, t. 3, Warszawa 1982, s. 438-440. 
Łepkowski T., Polska - narodziny nowoczesnego narodu 1764-1870, Warszawa 1967.

Mościcki H., Pozgonna cześć dla Księcia Józefa. Pogrzeb - pomniki - pieśni i legenda, Warszawa [b.r.].

Pachoński J., Koniec Legionów 1806-1807, w: Sprawozdania z posiedzeń Komisji Oddziału PAN w Krakowie, Kraków 1960, s. 107-112.

Pachoński J., Konopka Jan, w: Polski stownik biograficzny, t. 13, Wrocław-Warszawa-Kraków 1967-1968, s. 565-567.

Pachoński J., Legiony polskie. Prawda i legenda 1794-1807, t. 1, Działalność niepodległościowa i zaczątki legionów 1794-1797, Warszawa 1969.

Pachoński J., Legiony polskie. Prawda i legenda 1794-1807, t. 4, „Z ziemi włoskiej do Polski" 1800-1807, Warszawa 1979.

Pachoński J., Oficerowie Legionów Polskich 1796-1807, t. 1, Korpus oficerski Legionów Polskich 1796-1807, Kraków 1999.

Paluszewski J., Legenda literacka Księcia Józefa Poniatowskiego, Pruszków 2006.

Pasierb J. S., Kaznodziejstwo w religijnej i narodowej strukturze polskiego tysiaclecia, „Collectanea Theologica” 38 (1968), f. 2, s. 103-114.

Panuś K., Uratować naród! Głos z ambony katedry wawelskiej okresu niewoli narodowej 1795-1918, Kraków 1996.

Przybylski R., Klasycyzm czyli prawdziwy koniec Królestwa Polskiego, Warszawa 1983.

Rejman Z., Jan Pawet Woronicz. Poeta i kaptan, Chotomów 1992.

Sadlik M., Tu nie mowy lecz malarskiego trzeba pędzla (...) - wokót dwóch krakowskich pogrzebów: księcia Józefa Poniatowskiego i Jana Pawła Woronicza, w: Narodziny Rzeczpospolitej Krakowskiej. Relacje - obrazy - wspomnienia, red. M. Stankiewicz-Kopeć, T. Budrewicz, Kraków 2016, s. 123-136.

Skowronek J., Honor czy jedyna szansa? Polityczne dylematy Józefa Poniatowskiego w 1813 r., w: Francja-Polska XVIII-XIX w. Studia z dziejów kultury i polityki poświęcone Profesorowi Andrzejowi Zahorskiemu w sześćdziesiąta rocznicę urodzin, Warszawa 1983, s. 130-141.

Skowronek J., Książę Józef Poniatowski, Wrocław 1984.

Skowronek J., Poniatowski Józef Antoni, w: Polski stownik biograficzny, t. 27, Wrocław-Warszawa-Kraków-Gdańsk-Lódź 1983, s. 428-436.

Węgrzyn I., Książę Józef Poniatowski. Polskość w pulapce honoru, w: Książę Józef Poniatowski w kulturze i edukacji, red. Z. Budrewicz, T. Budrewicz, M. Chrobak, Kraków 2014, s. 31-44.

Wyczawski H. E., Szaniawski Franciszek Ksawery, w: Stownik polskich teologów katolickich, t. 4, Warszawa 1983, s. 248-250.

Wyczawski H. E., Szweykowski Wojciech Anzelm, w: Stownik polskich teologów katolickich, t. 4, Warszawa 1983, s. 287-289. 
Zamoyski A., Święte Szaleństwo. Romantycy, patrioci, rewolucjoniści 1776-1871, thum. M. Ronikier, Kraków 2015.

Ziółek E. M., O cnotliwym urzędniku i dobrym obywatelu. Kanonika Augustyna Lipińskiego filozofia sprawowania władzy (na kanwie kazania wygłoszonego 8 maja 1810 roku w Krakowie), „Roczniki Humanistyczne” 61 (2013), z. 2, s. 283-293.

Związek J., Rzeczywistość historyczna w kazaniach, Częstochowa 2009.

Żbikowska M., Nabożeństwo żałobne po śmierci Józefa Poniatowskiego. Rytual a mit, w: Francja-Polska XVIII-XIX w. Studia z dziejów kultury i polityki poświęcone Profesorowi Andrzejowi Zahorskiemu w sześćdziesiąta rocznicę urodzin, Warszawa 1983 , s. 173-182.

\section{Streszczenie}

Po 1795 r., po upadku państwa, Polacy, aby je odzyskać, musieli chwycić za broń i walczyć o niepodległość. O tej walce dowiedzieć się można było również z kazań i mów okolicznościowych czasów Księstwa Warszawskiego i Królestwa Polskiego, wygłaszanych na pogrzebach, przed rozpoczęciem obrad sejmu, na nabożeństwach z udziałem wojska oraz na uroczystościach organizowanych ku czci panujących. Ich autorzy, duchowni, opowiadali o doświadczeniu polskiego żołnierza, jakim była bohaterska walka w różnych częściach świata pod przewodem Napoleona Bonapartego, a która to walka miała doprowadzić do wskrzeszenia Polski. Zarazem kaznodzieje przedstawiali rodzimych żołnierzy doby napoleońskiej, jako dziedziców staropolskiego męstwa i bojowników narodowej sprawy, których wzorcowym reprezentantem stawał się książę Józef Poniatowski. Postać zaś i losy księcia, jak i jego współtowarzyszy broni, utrwalone przez legendę napoleońską, będą inspirowały następne pokolenia walczące o wolność Polski.

Słowa klucze: kazania, żołnierze polscy, Napoleon, Józef Poniatowski

\section{The Fate of Polish Soldiers During the Napoleonic Era in Light of Sermons and Speeches from the Period of the Duchy of Warsaw and the Kingdom of Poland}

\section{Summary}

After the collapse of the state in 1795, Poles had to take up arms and fight in order to regain independence. During the time of the Duchy of Warsaw and the Kingdom of Poland, this struggle was mentioned in sermons and speeches delivered at funerals, before the start of the parliamentary debate, at services with the army and during ceremonies organized in honor of the rulers. Their authors of these speeches, clergymen, spoke about the experiences of Polish soldiers in Napoleon's army and in their heroic fight in various parts of the world, which was to lead to the resurrection 
of Poland. At the same time, the preachers portrayed native Napoleonic soldiers as heirs to old Polish bravery and fighters of the national cause, whose prime representative was Prince Józef Poniatowski. The figure and fate of the prince, as well as his brothers in arms, perpetuated by the Napoleonic legend, would inspire the next generations fighting for Poland's freedom.

Key words: sermons, Polish soldiers, Napoleon, Józef Poniatowski 